\title{
PENINGKATAN KEMAMPUAN MENULIS CERPEN MELALUI PENERAPAN METODE PARTISIPATORI SISWA KELAS VII SMPN 1 PALLANGGA KABUPATEN GOWA.
}

\author{
Andi Paida \\ Fakultas Keguruan dan Ilmu Pendidikan,Universitas Muhammadiyah Makassar \\ andipaidahadli@gmail.com.
}

\begin{abstract}
This research was a classroom action research. The research aimed to improve learning outcomes in subjects Indonesian students of class VII SMPN1 Pallangga Gowa through Participatory methods of aspects of the ability to write short stories. Subjects of this study were students of class VII in the first semester of the school year the number of students 2013/2014 41 people. This study was conducted in two cycles, each cycle of meetings held 4 times. Data collection performed by using the achievement test, and the observation sheet. Learning outcomes data were analyzed by using quantitative analysis, while data on observations and student responses analyzed using qualitative analysis. The results showed that the average score of student learning outcomes in the first cycle of 76.95 with a standard deviation from an ideal score of 100, while the second cycle obtained an average score of 77.80 from the ideal score 100 An increase in the thoroughness of the student learning outcomes 37 students (90.24\%) which is in the category completed the first cycle to 40 students (97.56\%) in the second cycle is already above the 85\% completeness limit of classical learning dengaan score of at least 65 per student. Thus, the hypothesis is accepted.
\end{abstract}

Keywords: Short Story Writing Ability Students, Participatory Methods.

\begin{abstract}
Abstrak
Penelitian ini adalah penelitian tindakan kelas (Classroom Action Research) yang bertujuan untuk meningkatkan hasil belajar pada mata pelajaran bahasa Indonesia siswa kelas VII SMPN 1 Pallangga Kabupaten Gowa melalui metode Partisipatori terhadap aspek kemampuan menulis cerpen. Subjek dari penelitian ini adalah siswa kelas VII pada semester ganjil tahun ajaran 2013/2014 dengan jumlah siswa 41 orang. Penelitian ini dilaksanakan dalam dua siklus, masing-masing siklus dilaksanakan sebanyak 4 kali pertemuan. Pengambilan data dilakukan dengan menggunakan tes hasil belajar, dan lembar observasi. Data hasil belajar yang terkumpul dianalisis dengan menggunakan analisis kuantitatif, sedangkan data hasil observasi dan respon siswa dianalisis dengan menggunakan analisis kualitatif. Hasil penelitian menunjukkan bahwa skor rata-rata hasil belajar siswa pada siklus I sebesar 76,95 dengan standar deviasi dari skor ideal 100 sedangkan pada siklus II diperoleh skor rata-rata sebesar 77,80 dari skor ideal 100. Terjadi peningkatan ketuntasan hasil belajar siswa dari 37 siswa (90,24\%) yang berada pada kategori tuntas pada siklus I menjadi 40 siswa (97,56\%) pada siklus II sudah
\end{abstract}


berada di atas $85 \%$ batas ketuntasan belajar klasikal dengaan skor minimal 65 per siswa. Dengan demikian, hipotesis diterima.

\section{Kata Kunci : Menulis Cerpen, Siswa, Metode Partisipatori.}

\section{PENDAHULUAN}

Bahasa atau language merupakan produksi dari alat-alat bicara manusia (organ of speach) digunakan sebagai alat berkomunikasi dan berinteraksi. Bahasa mempunyai peranan yang sangat penting dalam kehidupan ini. Menurut Bloomfield language plays a gereat. Part in our life ( 1935: 3 ). Fakta menunjukan bahwa manusia dapat saja menggunakan alat komunikasi lain selain bahasa. Namun, bahasa verbal tetap merupakan alat komunikasi yang paling baik dan sempurna.

Kurikulum Tingkat Satuan Pendidikan (KTSP) 2006 tercantum bahwa salah satu tujuan pengajaran bahasa Indonesia di SMP adalah (1) pengembangan pengetahuan dan konsep-konsep bahasa yang bermanfaat dan dapat diterapkan dalam kehidupan sehari-hari, (2) mengembangkan rasa ingin tahu, sikap positif dan kesadaran tentang adanya hubungan yang saling mempengaruhi antara bahasa Indonesia, lingkungan, teknologi dan masyarakat, (3) mengengembangkan keterampilan proses untuk menyelidiki, memecahkan masalah dan membuat keputusan.

Tarigan (1982:

mengemukakan bahwa menulis merupakan keterampilan berbahasa yang dipergunakan untuk berkomunikasi secara tidak langsung, tidak secara tatap muka dengan orang lain. Menurut S. Takala (dalam Ahmadi, 1990: 24) bahwa menulis atau mengarang adalah suatu proses menyusun, mencatat, dan mengomunikasikan makna ganda, bersifat interaktif dan diarahkan untuk mencapai tujuan tertentu dengan menggunakan suatu sistem tanda konvensional yang dapat dilihat (dibaca).

\section{Cerita Pendek (Cerpen)}

Menurut Edgar Allan Poe (dalam Purba, 2010:50), bahwa Cerpen adalah karya sastra yang tidak panjang cukup dibaca sekali duduk, bertitik berat pada satu masalah dan memberi kesan tunggal. Dari beberapa pendapat di atas penulis menyimpulkan bahwa yang dimaksud dengan cerpen adalah cerita yang pendek yang panjangnya sekitar 5000 kata atau kira - kira 17 halaman kuarto spasi rangkap yang bersifat fiktif yang menceritakan suatu peristiwa dalam kehidupan pelakunya, ceritanya relatif singkat tetapi padat.

\section{Metode Partisipatori}

Metode partisipatori adalah metode pembelajaran yang lebih menekankan keterlibatan siswa secara penuh. Peserta didik dianggap sebagai penentu keberhasilan belajar. Peserta didik didudukkan sebagai subjek belajar dimana siswa berpatisipasi aktif, dapat menemukan hasil belajar dan guru sebagai fasilitator hanya bersifat sebagai pemandu atau fasislitator..

Menurut Freire(dalam Fakih, 2001:58), sebagai pemandu, guru diharapkan memiliki watak sebagai 
berikut :(1).Kepribadian yang menyenangkan dengan kemampuannya menunjukkan persetujuan dan apa yang dipahami partisipan.(2)Kemampuan sosial dengan kecakapan menciptakan dinamika kelompok secara bersamasama dan mengontrolnya tanpa merugikan partisipan. (3).Mampu mendesain cara memfasilitasi yang dapat membangkitkan partisispan selama proses barlangsung.(4). Kemamapuan mengorganisasi proses dari awal hingga akhir.(5). Cermat dalam melihat persoalan pribadi partisipan dan berusaha memberikan jalan agar partisipan menemukan jalannya.(6). Memiliki ketertarikan kepada subjek belajar.(7).Fleksibael dalam merespon perubahan kebutuhan belajar partisispan.(8).Pemahaman yang cukup atas materi pokok kursus pembelajaran.

\section{METODE PENELITIAN}

\section{a. Jenis Penelitian}

Jenis penelitian ini adalah penelitian tindakan kelas (Classroom Action Research). Penelitian ini dilakukan untuk meningkatkan hasil belajar pada mata pelajaran bahasa Indonesia siswa kelas VII SMPN 1 Pallangga Kabupaten Gowa melalui metode Partisipatori terhadap aspek kemampuan menulis cerpen. Adapun prosedur pelaksanaannya dengan dua siklus.

\section{b. Lokasi dan Subjek Penelitian}

Lokasi penelitian ini dilakukan di Sekolah Menengah Pertama Negeri 1 Pallangga Kabupaten Gowa Subjek penelitian ini adalah siswa kelas VII pada semester ganjil tahun ajaran
2013/2014 dengan jumlah siswa 41 orang.

\section{c. Instrumen Penelitian}

Istrumen adalah alat yang digunakan untuk memperoleh data sesuai dengan tujuan penelitian. Istrumen yang digunakan dalam penelitian ini adalah pedoman observasi, wawancara, dan tes

\section{d. Teknik Analisis Data}

Data yang terkumpul dianalisis dengan menggunakan teknik analisis kuantitatif dan analisis kualitatif. Untuk analisis kuantitatif digunakan statistik deskriptif, yaitu rata-rata dan persentase, standar deviasi, tabel frekuensi, persentase nilai terendah dan nilai tertinggi, sedangka analisis kualitatif yang digunakan adalah kategorisasi yang digunakan untuk menggunakan skor.

\section{e. Indikator keberhasilan}

Indikator keberhasilan dalam penelitian ini adalah bila skor rata-rata hasil menulis cerpen siswa mengalami peningkatan. menurut ketentuan Depdiknas 2006, siswa dikatakan tuntas apabila memperoleh skor minimal 70 keatas, dan tuntas secara klasikal apabila $85 \%$ ke atas dari jumlah siswa yang memperoleh skor minimal 65.

\section{HASIL PENELITIAN DAN PEMBAHASAN}

a. Hasil Penelitian

Penelitian ini dilaksanakan dalam dua siklus pada tahap pelakasanaan dengan menerapan metode Partisipatori untuk meningkatkan kemampuan menulis cerpen siswa kelas VII SMPN 1 Pallangga Kabupaten Gowa 


\section{Siklus I Analisis data Kuantitatif}

1) Perencanaan

2) membuat skenario pembelajaran;

3) membuat rencana pelaksanaan pembelajaran;

4) membuat lembar kerja siswa;

5) membuat lembar observasi sebagai alat pengumpul data untuk mengetahui bagaimana kondisi belajar mengajar di kelas pada waktu berlangsungnya kegiatan pembelajaran, baik siswa maupun guru;

6) membuat alat evaluasi.

\section{Observasi}

a. Peneliti memperhatikan keseluruhan siswa untuk mengetahui siapa yang hadir dan siapa yang tidak hadir.

b. Pemantauan keaktifan siswa pada saat pembelajaran berlangsung berdasarkan format yang telah disiapkan.

\section{Refleksi}

Kegiatan yang dilakukan pada tahap ini adalah menganalisis data yang diperoleh pada tahap perencanaan, observasi, dan aksi. Berdasarkan hasil analisis data dilakukan refleksi guna melihat kekurangan dan kelebihan yang terjadi pada saat pembelajaran. Kekurangan dan kelebihan ini dijadikan acuan untuk merencanakan siklus berikutnya.

Hasil analisis deskriptif skor perolehan siswa setelah diterapkan model pembelajaran dengan menggunakan penerapan metode partisipatori untuk menulis cerpen siklus I menunjukkan bahwa skor rata-rata hasil belajar siswa kelas VII SMPN 1 Pallangga Kabupaten Gowa melalui penerapan metode partisipatori pada siklus I sebesar 73,21. Skor yang dicapai responden tersebar dengan skor tertinggi 100 dan skor terendah 50 dari skor tertinggi yang mungkin dicapai 100 dan skor terendah yang mungkin dicapai 50. Hal ini menunjukkan bahwa tingkat kemampuan siswa cukup bervariasi.

Distribusi Frekuensi dan Persentase Skor Hasil Belajar Bahasa Indonesia Kelas VII SMPN 1 Pallangga Kabupaten Gowa pada Akhir Siklus I

\begin{tabular}{|c|c|c|c|}
\hline Skor & Kategori & Frekuensi & Persentase (\%) \\
\hline $50-59$ & Sangat rendah & 1 & $2,43 \%$ \\
\hline $60-69$ & Rendah & 7 & $17,07 \%$ \\
\hline $70-79$ & Sedang & 15 & $36,58 \%$ \\
\hline $80-89$ & Tinggi & 8 & $19,51 \%$ \\
\hline $90-100$ & Sangat tinggi & 10 & $24,39 \%$ \\
\hline
\end{tabular}

Dari 41 siswa kelas VII SMPN 1 Pallangga Kabupaten Gowa persentase skor hasil belajar siswa setelah penerapan metode partisipatori, ada 2,43 \% siswa yang berada pada kategori sangat rendah, $17,07 \%$ siswa berada pada kategori rendah, 36,58 \% siswa 
berada pada kategori sedang, 19,51

$\%$ siswa berada pada kategori tinggi, dan $24,39 \%$ siswa berada pada kategori sangat tinggi
Distibusi

Frekuensi

Ketuntasan Skor Hasil Belajar Bahasa Indonesia Kelas VII SMPN 1 Pallangga Kabupaten Gowa pada Akhir Siklus I

\begin{tabular}{|c|c|c|c|}
\hline Skor & Kategori & Frekuensi & Persentase (\%) \\
\hline $0-69$ & Tidak tuntas & 8 & $19,51 \%$ \\
\hline $70-100$ & Tuntas & 33 & $80,48 \%$ \\
\hline \multicolumn{2}{|c|}{ Jumlah } & 41 & 100 \\
\hline
\end{tabular}

Dari $41 \quad$ siswa terdapat $19.51 \%$ atau 8 siswa yang belum tuntas belajar dan80,48\% atau 33 siswa yang tuntas belajar. Ini berarti ketuntasan belajar pada siklus I sudah tercapai secara klasikal karena jumlah siswa yang tuntas sudah lebih dari $85 \%$. Di samping itu nilai rata-rata pada siklus I sudah mencapai KKM yang ditetapkan yaitu nilai rata-rata di atas 70 .

\section{Siklus II Analisis data Kuantitatif}

Berdasarkan hasil analisis data dapat diperoleh skor rata-rata hasil belajar siswa pada siklus II sebesar 77,80. Jika skor rata-rata siswa tersebut dimasukkan pada tabel 4.5, maka skor rata-rata berada pada kategori tinggi. Hal ini berarti bahwa rata-rata peningkatan hasil belajar siswa kelas VII SMPN 1 Pallangga Kabupaten Gowa setelah dilaksanakan pembelajaran bahasa Indonesia dengan peneraapan metode partisipatori berada pada kategori tinggi.

\section{Distibusi}

Frekuensi

Ketuntasan Skor Hasil Belajar Bahasa Siswa Kelas VII SMPN 1

Pallangga Kabupaten Gowa pada Akhir Siklus II

\begin{tabular}{|c|c|c|c|}
\hline Skor & Kategori & Frekuensi & Persentase (\%) \\
\hline $0-69$ & Tidak tuntas & 1 & $2,43 \%$ \\
\hline $70-100$ & Tuntas & 40 & $97,56 \%$ \\
\hline \multicolumn{2}{|c|}{ Jumlah } & 41 & $100 \%$ \\
\hline
\end{tabular}

Berdasarkan data menunjukkan bahwa hasil belajar bahasa Indonesia siswa mengalami peningkatan dengan menerapkan metode partisipatori untuk meningkatkan kemampuan menulis cerpen untuk siklus I sebanyak $90,24 \%$ atau 37 dari 41 siswa dikatakan tuntas, sedangkan pada siklus II sebanyak $97,56 \%$ atau 40 dari 41 siswa hasil belajarnya lebih maksimal.

Hasil analisis deskriptif di atas menunjukkan bahwa hasil belajar bahasa Indonesia Kelas VII 
SMPN 1 Pallangga Kabupaten Gowa setelah penerapan metode prtisipatori untuk meningkatkan kemampan menulis cerpen mengalami peningkatan. Hal ini terlihat dari peningkatan skor ratarata yang diperoleh siswa dari 73,21 pada Siklus I menjadi ,77,80 pada Siklus II

\section{b.Pembahasan}

Berdasarkan hasil analisis pelaksanaan siklus I hasil peningkatan kemampuan menulis cerpen melalui penerapan metode partisipatori siswa SMPN 1 Pallangga Kabupaten Gowa dapat dijelaskan sebagai berikut: ada 10 orang siswa yang berada pada kategori sangat tinggi dari 41 siswa, yang memperoleh skot tinggi ada 8 orang dari 41 siswa, yang memperoleh skor sedang ada 15 orang dari 41 siswa, rendah 7 orang dari 41 siswa dan yang memperoleh skor sangat rendah 1 tidak ada. Apabila nilai skor perolehan siswa dirata-ratakan persen.

Berdasarkan hasil analisis pelaksanaan siklus I hasil kemampuan menulis cerpen melalui penerapan metode partisipatori siswa SMPN1 Pallangga Kabupaten Gowa dapat dijelaskan sebagai berikut: ada 7 orang siswa memperoleh skor sangat tinggi dari 41 (17,07\%), siswa yang memperoleh skor tinggi 9 orang dari 41 siswa $(21,95 \%)$, yang memperoleh skor sedang 24 orang dari 41 siswa $(58,53 \%)$, ada $1(2,43 \%)$ orang siswa yang memperoleh rendah dan $0(0)$ orang siswa yang sangat rendah. Nilai rata- rata tersebut dibandingkan dengan nilai UASBN Bahasa Indonesia tahun ajaran 2011/2012 yaitu nilai ratarata 65,00 menunjukkan bahwa nilai latihan kemampuan menulis terhadap perkembangan kemampuan berbahasa dalam penelitian ini masih lebih baik.

Nilai ketuntasan siswa pada siklus II $97,56 \%$ atau 41 orang termasuk dalam kategori tuntas. Hal ini berarti bahwa indikator keberhasilan terpenuhi yaitu standar ketuntasan klasikal 65 persen. Dengan demikian terjadi peningkatan hasil ketuntasan kemampuan menulis cerpen dari siklus I ke siklus II.

Rata-rata peningkatan aktivitas siswa adalah 90,24 persen pada siklus I dan 97,56 persen pada siklus II. Selain terjadi peningkatan hasil belajar menulis cerpen dari siklus I ke siklus II terjadi pula perubahan sikap siswa dalam proses pembelajaran perubahan tersebut merupakan data kualitatif yang diperoleh dari lembar observasi pada setiap pertemuan yang dicatat pada tiap siklus.

\section{Refleksi Pelaksanaan Tindakan I}

Pada siklus I, pertemuan pertama penelitian. Kegiatan latihan berlangsung cukup baik dimana awal latihan setiap kelompok menerjakan latihan dengan antusias namun kendala yang dihadapi adalah ada beberapa siswa yang berpartisipasi dalam kelompok 
a) Pada pertemuan kedua masih ada kelompok yang belum mampu mempresentasikan hasil diskusinya namun guru dapat memberi motivasi sehingga proses belajar mengajar berlangsung lancar.

b) Ketuntasan belajar siswa kelas VII adalah 90,24 persen.

\section{Refleksi Pelaksanaan Tindakan}

II

a. Pada siklus II terjadi peningkatan keaktifan siswa dalam proses belajar diliat dari aktivitas siswa yang bekerjasama dalam kelompok meningkat.

b. Ketuntasan pada penerapan metode partisipatori dalam meningkatkan kemampuan menulis cerpen siswa kelas VII SMPN 1 Pallangga Kabupaten Gowa meningkat dari siklus I adalah 90,24 persen dan siklus II adalah 90,56 persen.

\section{V. Simpulan dan Saran}

Menulis merupakan bagian yang tak terpisahkkan dalam seluruh proses belajar yang dialami peserta didik selama proses pembelajaran. Pada setiap semester, mereka harus menulis makalah atau tulisan lainnya, adakalanya untuk seluruh mata pelajaran yang ditempuh. Dengan demikian, mereka mengharapkan akan memiliki wawasan yang lebih luas dan mendalam mengenai topik yang ditulisnya.

Berdasarkan hasil analisis data dan pembahasan maka dapat ditarik kesimpulan bahwa Kemampuan menulis cerpen melalui penerapan metode partisipatori mengalami peningkatan, yaitu pada siklus I skor rata-rata hasil belajar siswa kelas VII SMPN 1 Pallangga Kabupaaten Gowa dari 73,21 pada siklus I menjadi 77,80 pada siklus II dari skor ideal 100 setelah diterapkan metode pembelajaran yakni metode partisipatori pada kemampuan menulis cerpen. Terjadi peningkatan ketuntasan hasil belajar siswa kelas VII SMPN 1 Pallangga Kabupaten Gowa dari 37 orang $(90,24 \%)$ yang berada pada kategori tuntas pada siklus I menjadi 40 orang $(97,56 \%)$ pada siklus II.Terjadi peningkatan persentase kehadiran, keaktifan, keberanian dan rasa percaya diri siswa dalam proses belajar mengajar sesuai dengan hasil lembar observasi yang diamati selama pelaksanaan penelitian.

\section{DAFTAR PUSTAKA}

Akhadiah Sabarti, G. Arsjad Maidar. 1991. Pembinaan Kemampuan Menulis Bahasa Indonesia, Jakarta: Erlangga.

Alwi, dkk, 2003. Kamus Besar Bahasa Indonesia. Surabaya: Apollo.

Aqib, Zaenal. 2008. Penelitian Tindakan Kelas. Bandung: Irama Madya.

Arikunto,Suharsimi. 2006. Penelitian Tindakan Kelas. Jakarta : PT.Bumi Aksara.

Daryanto Sigit. 1998. Kamus Lengkap Bahasa Indonesia. Surabaya: Apollo. 
Depdiknas.2004:P.3. Kurikulum Berbasis

Kompetensi Mata Pelajaran

Bahasa dan Sastra Indonesia.

Jakarta: Depdikbud.

Depdiknas.2006. Kurikulum Tingkat

Satuan Pendidikan (KTSP),

Jakarta.

Rosdiana. 2010. Peningkatan Kemampuan

Menulis cerpen Melalui

MetodeKooperatif Tipe Jingsaw

Kelas IX SMP Askari Pallangga

Kabupaten Gowa.

Rusman. 2013. Model-Model

Pembelajaran: Mengembangkan

Tarigan Henry Guntur. 1994. Menulis

sebagai Suatu Keterampilan

Berbahasa Bandung: Angkasa.

Widyamartaya, Alois dan Vero Sudiati.

2005, Kiat Menulis Deskripsi dan Narasi, Lukisan Dan Cerita . Yogyakarta: Pustaka Widya.

Yamin Martinis H. 2012. Desain Baru Pembelajaran Konstruktivistik. Jakarta:Referensi. 